\title{
Probabilistic modeling of overhead irrigation processes*
}

\section{A. Chernovolov**, L. V. Kravchenko***, V. B. Litvinov**, A. N. Nikitina****,}

\section{A. A. Filina ${ }^{* * * * *}$}

Azov-Black Sea Engineering Institute, Zernograd, Russian Federation

Don State Technical University, Rostov-on-Don, Russian Federation

Southern Federal University, Rostov-on-Don, Russian Federation

Supercomputers and Neurocomputers Research Center Co., Taganrog, Russian Federation

The article is devoted to the development of a sprinkling process model that is in relation to the probabilistic similarity to the simulated process, the numerical implementation of which allows to calculate the matrix of irrigation doses in the sprinkling area, or at the test site. The study was performed using system analysis and probabilistic modeling. The uniform distribution of fluid over the area until 2004 was estimated by the RD 10.11.1-9-89 by the effective irrigation coefficient, insufficient irrigation coefficient, and excessive irrigation coefficient. After the introduction of the interstate standard ISO 7749-2-2004 it is estimated by the Christiansen coefficient. New mathematical models and software were designed for probabilistic modeling of the sprinkling process. In constructing the model, the event combining theorem and the Lyapunov theorem were used. As the example, analysis of the operation of twelve sprinklers was carried out. The presented computational experiment was performed to optimize the positioning of the apparatuses according to the criteria of irrigation uniformity and the coefficient of ac-counting completeness of water, which falls on the test site. The obtained results can be used in the process of optimizing the placement of vehicles on «Volzhanka» and «Dnepr» machines. Probabilistic mathematical models of the sprinkling process make it possible to optimize the positioning of apparatuses according to the criteria of uniform irrigation. The programs for modeling water distribution by devices from four positions are applicable only when the distance between the positions is greater than the radius of the sprinkling zone. Irrigation uniformity indicators do not meet agrotechnical requirements. Optimization of the positioning of the apparatus in twelve positions provides excellent indicators for irrigation uniformity. The optimization programs and techniques that were used in the study are applicable to optimize the distribution of other liquids in agricultural technologies, for example, for the distribution of pesticides.

\footnotetext{
* The reported study was funded by RFBR according to the research project № 19-07-00623.

** E-mail: chernovolov.v@mail.ru, LitvinovVN@ rambler.ru.

*** E-mail: lusya306@yandex.ru.

**** E-mail: nikitina.vm@ gmail.com.

*****E-mail: j.a.s.s.y@mail.ru.
} 
Keywords: calculation of uniformity indicators, sprinkling uniformity, irrigation uniformity, Christiansen uniformity coefficient, effective irrigation coefficient, insufficient irrigation coefficient, excess irrigation coefficient.

Introduction. The purpose of the research is to design probabilistic model of the sprinkling process. That model is in relation to the probabilistic similarity to the simulated process, the numerical implementation of which is presented in the form of software that calculates matrix of irrigation doses in the irrigation zone, or at test site according to the water flow through the apparatus and statistical characteristics of the jet, performing imitation of the movement of the machine and the overlapping of zones from several vehicles, calculating indicators of irrigation uniformity at different steps of apparatus installation, issuing the result in the form of matrices or graphs.

The objective function of the sprinkling system is to reduce the unproductive water consumption while maintaining the irrigation rate by optimizing the sprinkling process using probabilistic modeling. Sprinklers do not require field layout. Some of them work with slopes of 0.05 and more. Exceeding the sprinkling intensity as compared with the soil absorbency in such field leads to flooding of some sites, to surface runoff, that is, to the increase of unproductive consumption of the most important natural resource and soil erosion, causing environmental damage to reservoirs that receive waste water, and reduction of crop yields and others.

Materials and methods. The study was performed using system analysis and probabilistic modeling. The uniform distribution of fluid over the area until 2004 was estimated by the RD 10.11.19-89 by the effective irrigation coefficient, insufficient irrigation coefficient, and excessive irri gation coefficient. After the introduction of the interstate standard ISO 7749-2-2004 it is estimated by the Christiansen coefficient.

Research results. The intensity of sprinkling should not exceed the absorbency of the soil. The effectiveness of the system is assessed by the compliance of the average dose, uniformity and intensity of sprinkling to the established standards. To assess the effectiveness of the system in the field the reporting area is to be indicated.

The size of the site is set by integers. The platform is divided into meter squares. There is set the cycles and calculated the coordinates of the middle of each meter square. According to the coordinates there is defined the distance of the squares to each of the devices involved in the irrigation of the test site. The distance matrix is used when calculating the sprinkling intensities from each apparatus. Intensities are summed to obtain an intensity matrix. By the intensity matrix, the uniformity index, the dose matrix, the average dose are calculated. The dosage matrix checks the fulfillment of the water intake condition and the absence of surface water flow. Calculation of the system performance indicators is conducted using software probabilistic process models that are designed further.

Defining the cycles of changing the distances between the devices, there is calculated the performance indicators for all values of the parameters A and B, optimal positioning of the devices is determined.

The most important step in system analysis is the design of adequate probabilistic models of the process. Improvement of the adequacy of the models is achieved using the statistical results of testing devices by the radial method. 
Design, testing and adjustment of sprinkling machines are associated with significant labor and material resources, and take a lot of time. The use of computer-aided design systems for these purposes allows to accelerate the designing of machines, reduce costs [2].

The rotation of the apparatus is considered to be uniform, if in one cycle of pulsed movement the displacement is significantly less than the size of the sprinkling zone. The device operates in a circle or sector.

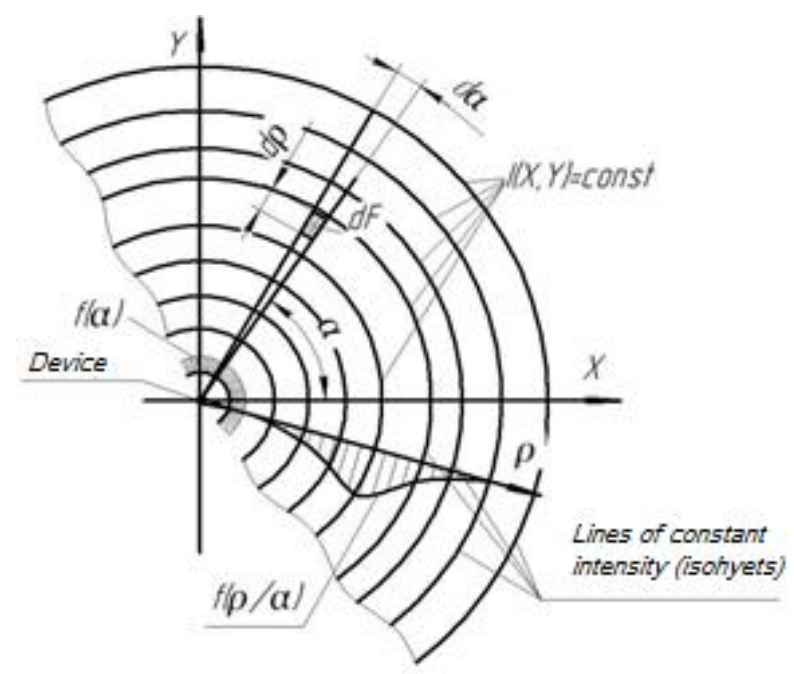

Fig. 1. Diagram of water distribution simulation with the sprinkling mashine

Sprinkler machines DShK-64A «Volzhanka» and DF-120 «Dnepr» work positionally. The Sprinkler machine DF-120 works from the hydrants located at distance of 54 meters. The pipeline is equipped with the flaps of 27 meters in length, at the ends of which medium jet sprinklers are installed. The layout of the apparatus during sprinkling can be represented as the rectangle with dimensions $A \times B$, where $A$ is the distance between the apparatus on the pipeline; $B$ is the distance between positions or flaps.

Stationary sprinkler systems have the same layout of the apparatus, therefore, the modeling of water distribution by such systems can be performed according to programs designed for positional action machines. For the programs to work, it is enough to obtain experimental data on the water distribution along the radii of the irrigation zone, the other characteristics are calculated by the simulation method.

Simulation is performed under the assumption of uniform rotation of the apparatus. In one cycle of impulse movement, the displacement is significantly smaller than the size of the sprinkling zone, therefore, after the overlapping of the sprinkling zones, the distribution of water is obtained in the same way as with uniform continuous rotation of the apparatus. The apparatus of such machines usually work in a circle.

Sprinklers create rain fan that irrigates circle on the field. The area that is irrigated by one apparatus is called the sprinkling zone. 
Mathematical models of the process are presented under the following assumptions (Fig. 1) rain distribution by fan angle or circle is known and defined by empirical density of angle probability $f(\alpha)$ and flow $Q$; density of the water flow per angle unit equals to $q_{\alpha}=Q \cdot f(\alpha)$; the distribution of the flight distance of the droplets by radius is known and given by the empirical probability density of the distances $f(\rho)$; wind speed is zero; consumption $Q$ and installation height of the devices are constant; the surface of the field is horizontal.

Let the device be in the center of the $X O Y$ coordinate system and work in a circle (Fig. 1). The position of the site $d F$ is set in rectangular and polar coordinates. The need to have two coordinate systems is explained by the fact that the apparatus moves along angle and emits jet along radius, and the uniformity of rain must be determined by the area in rectangular coordinates.

Вероятность попадания жидкости на элементарную площадку $d F$, выделенную в зоне дождевания двумя радиусами с углом между ними $d \alpha$ и двумя окружностями с приращением радиуса $d \rho$, определится как произведение вероятностей попадания в диапазон угла $d \alpha$ и радиуса $d \rho$, т.е.

The probability of fluid entering elementary platform $d F$, that is marked in the sprinkling zone by two radii with the angle between them $d \alpha$ and two circles with increment of radius $d \rho$, is defined as the multiplication of the probabilities of falling into range of angle $d \alpha$ and radius $d \rho$, i.e.

$$
P\{d F\}=f(\alpha) \cdot d \alpha \cdot f(\rho) d \rho .
$$

The intensity of rain on the site is equal to the amount of water falling on it per unit of time divided by its area. With independent units $\rho$ and $\alpha$ it is

$$
I=\frac{Q \cdot f(\alpha) \cdot d \alpha \cdot f(\rho) \cdot d \rho}{\rho \cdot d \alpha \cdot d \rho}=\frac{Q \cdot f(\alpha) \cdot f(\rho)}{\rho} .
$$

In the SI system, the sprinkling intensity is measured in $\mathrm{kg} / \mathrm{m}^{2} \cdot \mathrm{s}$, which is equivalent to such usual units for land reclamation as mm of layer per second.

Initially, in formula (1), on the basis of the Lyapunov limit theorem, the normal laws of the distribution of the angle and distance of the jet's flight were applied. Subsequently, any empirical distribution was approximated by the method of cubic spline interpolation and the resulting function was used to calculate the intensities by the formula (1)

The dose of irrigation of any site by the stationary device is determined by the multiplication of the intensity and the operating time $T$, i.e.

$$
q_{F}=I \cdot T, \kappa 2 / \mathrm{M}^{2} \text {. }
$$

The rectangular coordinates of the site $d F$ are related to the polar relations:

$$
\left\{\begin{array}{l}
X=\rho \cdot \cos \alpha \\
Y=\rho \cdot \sin \alpha .
\end{array}\right.
$$

Inkjet apparatus when working in a circle rotates uniformly, therefore, all values of the angle are equally probable and the probability density of the angle is determined by the formula

$$
f(\alpha)=\frac{1}{2 \cdot \pi} .
$$


The probability density of drops' flight distance of a single-nozzle apparatus, such as the «Rosa$1 »$, is approximated by normal distribution law

$$
f(\rho)=\frac{1}{\sigma_{\rho} \sqrt{2 \cdot \pi}} \exp \left(-\frac{\left(\rho-M_{\rho}\right)^{2}}{2 \cdot \sigma_{\rho}^{2}}\right),
$$

where $\rho$ is drops' flight distance; $M_{\rho}, \sigma_{\rho}$ are mathematical expectation and standard deviation of drops' flight distance.

The probability density of drops' flight distance of apparatus with two nozzles is determined by the formula of the composition of the distribution laws

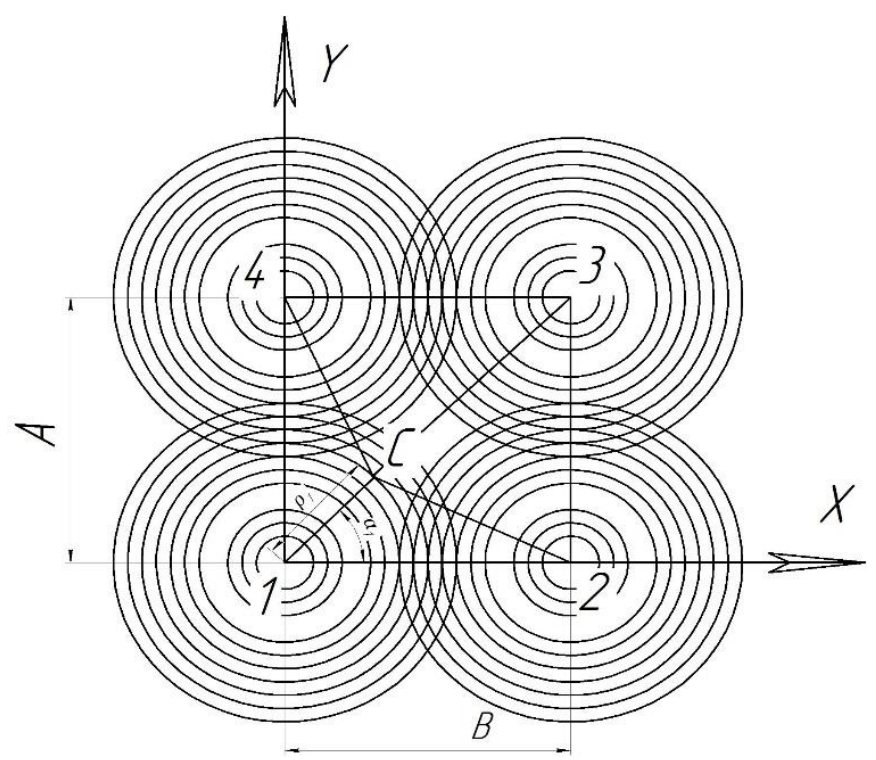

Fig. 2. Simulation scheme of water distribution by four sprinklers.

$$
f(\rho)=\frac{C_{1}}{\sigma_{\rho 1} \sqrt{2 \cdot \pi}} \exp \left(-\frac{\left(\rho-M_{\rho 1}\right)^{2}}{2 \cdot \sigma_{\rho 1}^{2}}\right)+\frac{C_{2}}{\sigma_{\rho 2} \sqrt{2 \cdot \pi}} \exp \left(-\frac{\left(\rho-M_{\rho 2}\right)^{2}}{2 \cdot \sigma_{\rho 2}^{2}},\right.
$$

where $C_{1}, C_{2}$ are weight coefficients; $M_{\rho 1}, \sigma_{\rho 1}$ are mathematical expectation and standard deviation of drops' flight distance from the first nozzle; $M_{\rho 1}, \sigma_{\rho 1}$ are mathematical expectation and standard deviation of drops' flight distance from the second nozzle.

The weight coefficients and numerical characteristics of the drops' flight distance are selected at modeling by the condition of the most uniform distribution of water by radius or by sprinkling area.

Further, there are proposed algorithms and programs for mathematical modeling and optimization of water distribution processes by stationary sprinklers or ones that are installed at positional action machine taking into account random and deterministic factors.

There is presented the modeling of water distribution using example of "Rosa-1" type irrigation system.

According to the technical characteristics of the device there is accepted $M_{\rho}=11 \mathrm{~m}$; $\sigma_{\rho}=3,2 m ; Q=1,21 / \mathrm{s}$. 
The first device is located at the beginning of coordinates $X O Y$, the second one is shifted along the $X$ axis by distance $\mathrm{B}$, the third one has coordinates of $(B, A)$, the fourth one has coordinates of $(0, A)$.

For clarity of modeling, there were set the dimensions of the general sprinkling area and calculated the irrigation dose by all four devices using the designed algorithm (Fig. 3).

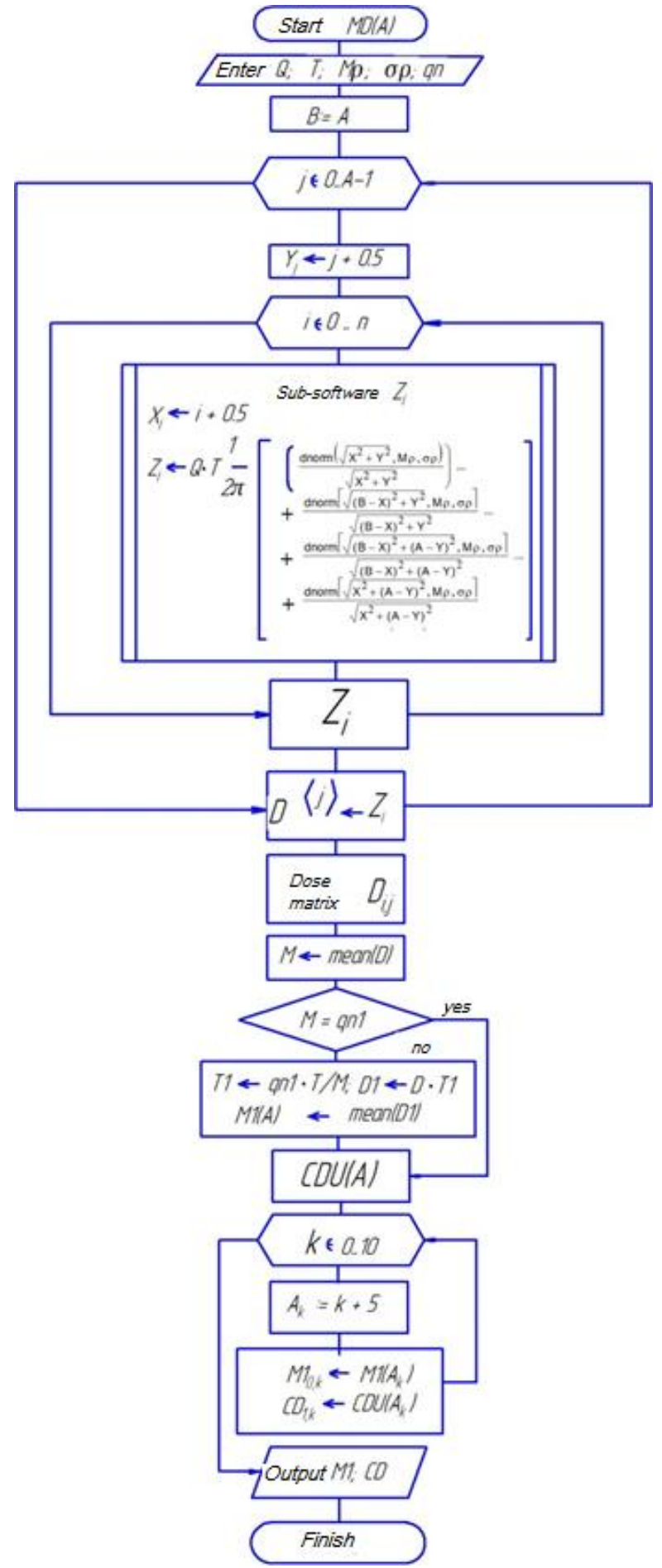

Fig. 3. Block diagram of calculation of doses and indicators of irrigation uniformity for four devices. 


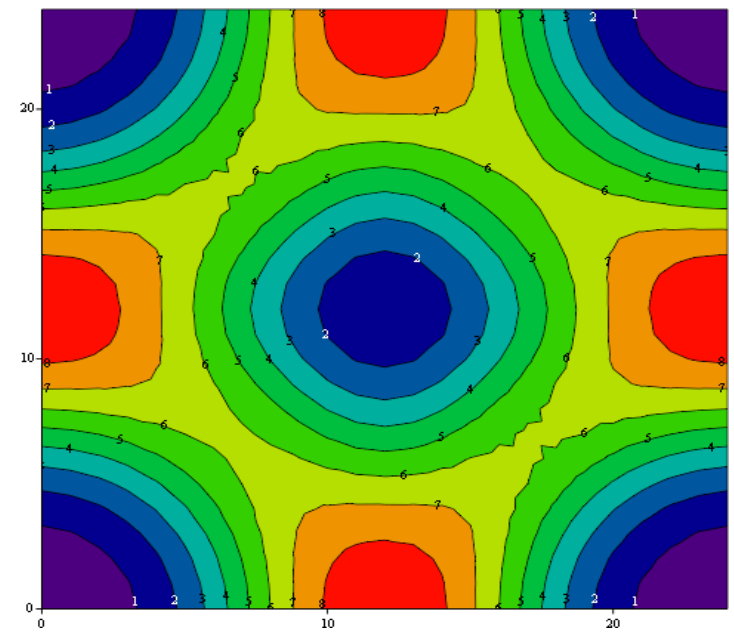

Fig. 4. The result of calculating the irrigation uniformity on the area irrigated by four devices at $A=B=25 \mathrm{~m}$

To do this, the coordinates of the point $C(X, Y)$ are set in the form of matrix with the step of one meter. Changing the distances between the devices, they were chosen under condition of more uniform water distribution. However, this task was quite difficult.

Quantitative assessment of uniformity on the rectangle area with dimensions $A$ and $B$ was performed using irrigation dose matrix. The limits of the $X, Y$ coordinates are set so that the square area bounded by the lines connecting the points of location of the apparatuses is divided into meter sections. Doses of sprinkling are calculated in the center of each site.

Based on the calculation results, there were obtain a matrix of doses $M D$ with the number of elements $A \cdot B$. According to the dose matrix, there were calculated the variation coefficients, the minimum, average and maximum doses for different values of $A$ and $B$. For calmness, it is logical to set $A=B$.

Variational series were compiled using dose matrices and the coefficients of effective, excessive and insufficient irrigation were calculated. The average dose was calculated by the matrix and compared with the value of

$$
q_{F s r}=\frac{Q \cdot T}{A \cdot B} \text {. }
$$

Studies have revealed the difficulty of obtaining uniform distribution of water with single-jet stationary devices. The coefficient of effective irrigation was much less agronomic standards. Overand under-irrigation ratios were twice the agronomic standard.

To perform the optimization, dose calculation softwares were designed for squares bounded by lines connecting the points of location of the apparatuses [3].

The algorithm has two cycles of calculating the coordinates of meter squares. In the center of each square, irrigation dose of is calculated, matrix $M_{i, j}$ is created. Next, there are calculated the average value of the elements of the dose. Check is performed for the absence of wastewater, if necessary, the sprinkling time is recalculated or the water flow through the apparatus is adjusted.

If the distance between positions $A$ is greater or equals to (Fig. 5, a) the maximum radius of sprinkling, then water from the four devices gets to the site $F$, bounded by lines connecting points 1 , 
$2,3,4$ of the devices' location. Its quantity is equal to the multiplication of flow through one apparatus at the sprinkling time.

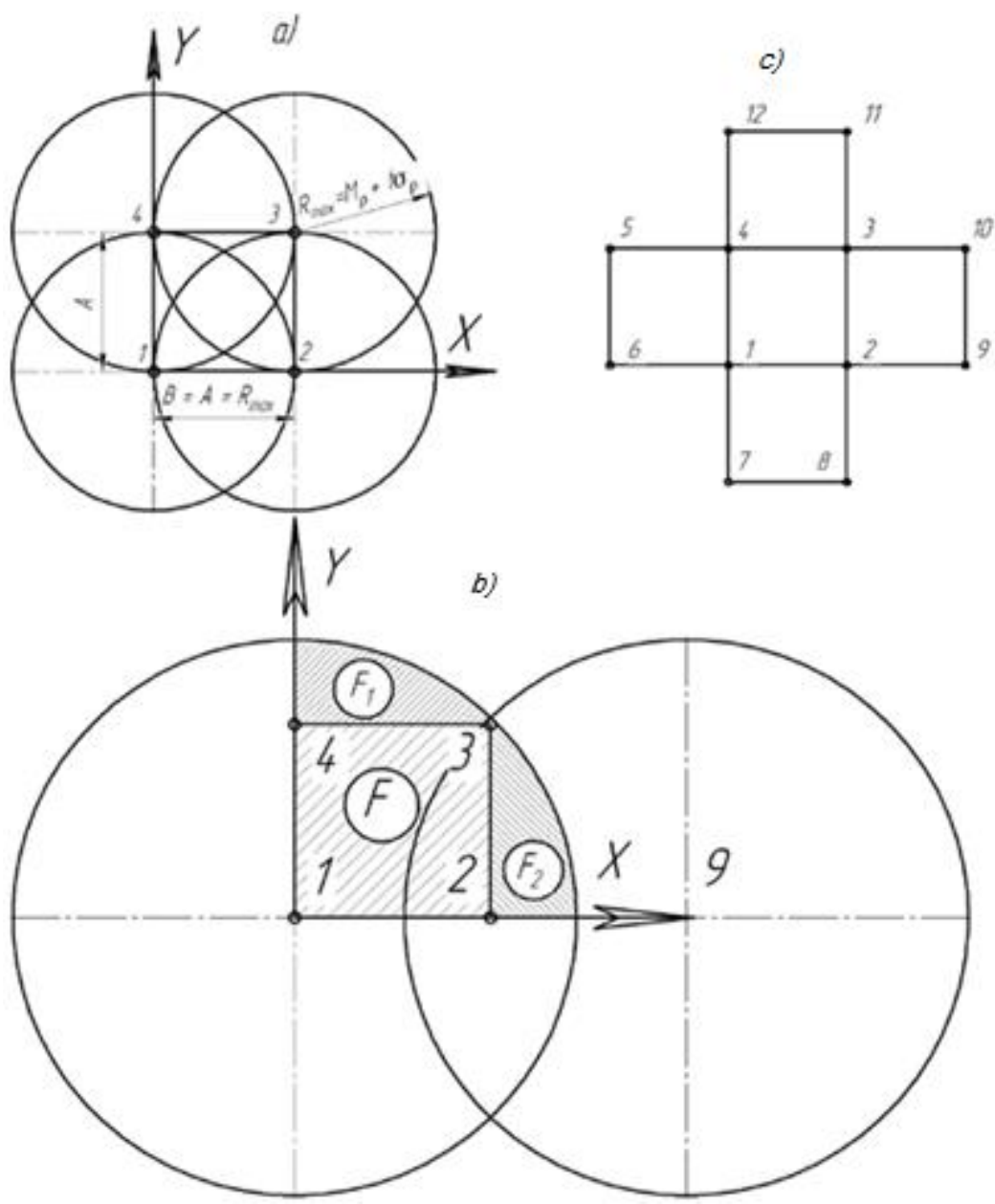

Fig. 5. Schemes of sprinkling model design

At site $F$, each device produces a fourth part of the flow, other devices do not participate in sprinkling the site. The models for calculating the sprinkling dose are relatively simple, the assessment of the irrigation uniformity of the entire field is the same as the test area $F$. However, as calculations presented, it is not possible to obtain distribution with a single-jet apparatus within limits. When the distance between the positions decreases (Fig. 5, b), the sprinkling area of the apparatus goes beyond the test site. The first apparatus has areas the water on which supplements the irrigation of adjacent areas irrigated with fourth and ninth positions (Fig. 6, c). In this case, accurate assessment of the sprinkling uniformity of the test site should be carried out taking into account the work of twelve vehicles according to Fig. 6, c.

The preliminary assessment can be performed on four devices, but to calculate the coefficient of completeness of accounting, that is equal to the ratio of the sum of doses on the test site to the product of the flow through one device for the watering time. The smaller this coefficient is than 1 , the less reliable is the uniformity estimation. The data of the matrix shows that with $A=10 \mathrm{~m}$ the distribution is very uniform, although the overlap is large. 
However, the coefficient of accounting completeness is less than 0.7 , therefore it is necessary to develop modeling software from twelve positions. Previously it can be noted the possibility of uniform watering with single-jet sprinklers.

Software $M D 12(A)$ is designed to calculate the dose of watering by twelve single-jet devices installed in the corners of the squares on the Fig. 5, c.

The test site is located between the devices 1, 2, 3, 4 .

Software $\mathrm{Ke} 12$ (A) [4] includes software MD12(A) and according to the dose matrix there is performed calculations of the Christiansen, insufficient, effective and excessive irrigation coefficients and the coefficient of accounting completeness. The program is supplemented with cycle of changing the distance between the positions.

The output of the calculation results in the form of matrix (Fig. 6) allows to select the optimal distance between the positions of the devices.

$\mathrm{i}:=0 . .4$
$\mathrm{M}=\left(\begin{array}{cccccccccc}96.448 & 96.738 & 98.251 & 91.012 & 83.152 & 76.818 & 72.146 & 67.974 & 64.464 \\ 0 & 0 & 0 & 0 & 0.071 & 0.204 & 0.231 & 0.297 & 0.304 \\ 1 & 1 & 1 & 0.972 & 0.781 & 0.571 & 0.516 & 0.469 & 0.346 \\ 0 & 0 & 0 & 0.028 & 0.148 & 0.224 & 0.253 & 0.234 & 0.349 \\ 0.976 & 0.991 & 0.997 & 0.999 & 0.999 & 0.999 & 0.999 & 0.999 & 0.999 \\ 9 & 10 & 11 & 12 & 13 & 14 & 15 & 16 & 17\end{array}\right) \quad\left(\begin{array}{c}\mathrm{CDU} \\ \text { Knd } \\ \text { Kef } \\ \text { Kiz } \\ \mathrm{Ky} \\ \mathrm{A}\end{array}\right)$

Fig. 6. Matrix of calculation results of uniformity indicators of water distribution by single-jet apparatus

Matrix in Fig. 6 shows that a single-jet apparatus distributes irrigation water in accordance with agrotechnical requirements only when the distance between positions is less than $13.5 \mathrm{~m}$. In this case, the Christiansen coefficient is about $80 \%$. The calculations were performed with the expectation of the drops' flight distance of $10 \mathrm{~m}$ and the standard deviation of the distances of $3 \mathrm{~m}$. Insufficient watering under the vehicles was eliminated by the fact that the maximum intensity of the adjacent apparatus almost coincides with the point of the neighboring one. When the distance between the apparatuses is less than $13.5 \mathrm{~m}$, the irrigation dose on all meter sites in the overlap zone equals to the agrotechnical limits $M(1 \pm 0,25)$. The coefficient of accounting completeness is equal to 0.997 , which testifies to the full account of the water flow to the teating site from twelve devices. The possibility of uniform irrigation using single-jet sprinklers is proven, but the distance between the positions is close to the mathematical expectation of the drops' flight distance.

The designations in Fig. 6 are written at the right of the counting matrix: $M_{0, j}$ is the Christiansen ratio; $M_{1, j}$ is the underflow coefficient; $M_{2, j}$ is the coefficient of effective watering; $M_{3, j}$ is the coefficient of over-irrigation; $M_{4, j}$ is the coefficient of accounting completeness; $A$ is the distance between the positions of the apparatus.

Fig. 6 shows that the coefficient of accounting completeness is very close to 1 . The coefficient of effective irrigation is 0.7 and the coefficient of uniformity according to Christiansen is obtained of 
0.8 when the apparatus is installed at step of $13.4 \mathrm{~m}$, which is one meter more than at the evaluation of four positions.

\begin{tabular}{|c|c|c|c|c|}
\hline 18 & 19 & 20 & 21 & \multirow[b]{2}{*}{$(\mathrm{CDU})$} \\
\hline 81.812 & 80.406 & 78.792 & 76.959 & \\
\hline 0.158 & 0.179 & 0.194 & 0.215 & Knd \\
\hline 0.711 & 0.679 & 0.654 & 0.616 & Kef \\
\hline 0.131 & 0.143 & 0.151 & 0.169 & $\mathrm{Kiz}$ \\
\hline 1.777 & 1.797 & 1.818 & 1.838 & $\mathrm{Ky}$ \\
\hline 38 & 39 & 40 & 41 & \\
\hline
\end{tabular}
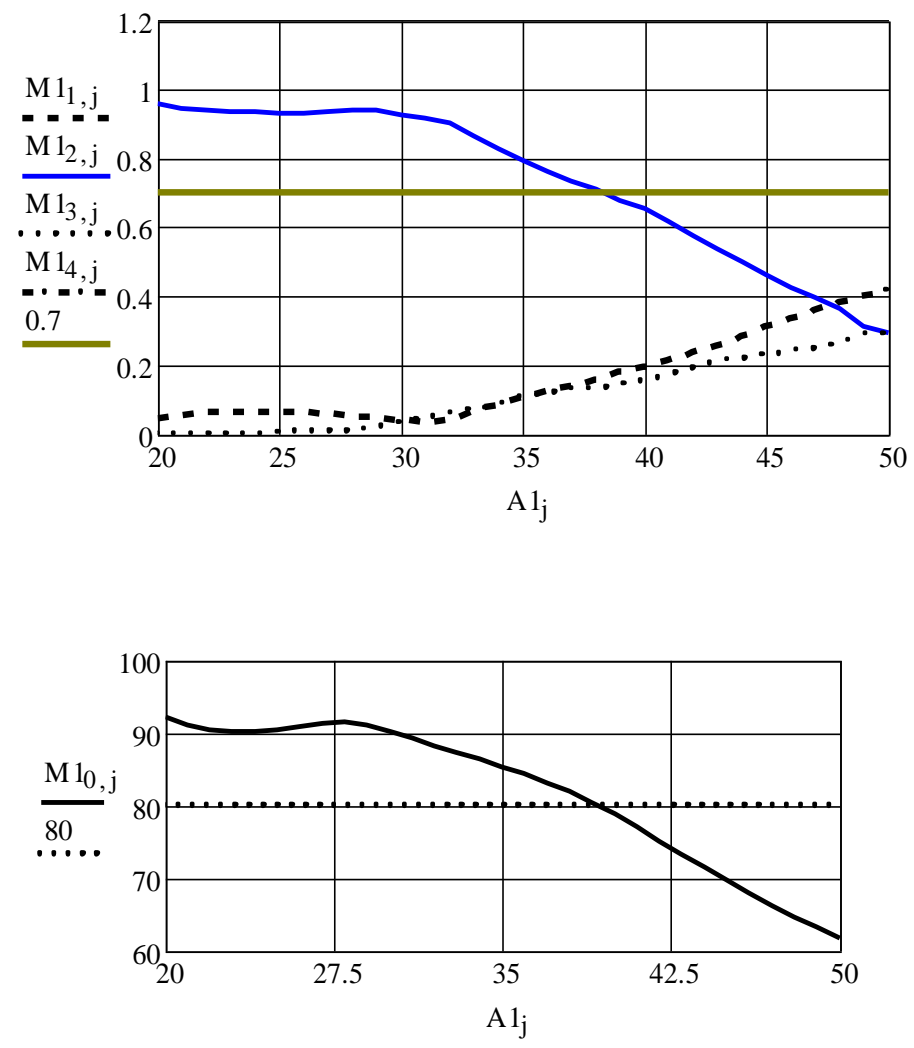

Fig. 7. Matrix of doses and graphs of indicators of uniform water distribution by a double-jet apparatus when working at twelve positions $M_{\rho 1}=15 m ; \sigma_{\rho 1}=5 m ; M_{\rho 2}=7 m, \sigma_{\rho 2}=2 m ; C_{1}=0,7 ; C_{2}=0,3$.

Next, simulation of the operation of the «Rosa-3» type apparatus was performed.

There was considered the work of the two main nozzles.

The following input data is accepted: $Q=8 \mathrm{l} / \mathrm{s} ; M_{\rho 1}=15 \mathrm{~m} ; \quad \sigma_{\rho 1}=5 \mathrm{~m} ; \quad M_{\rho 2}=7 \mathrm{~m}$, $\sigma_{\rho 2}=2 m ; C_{1}=0,7 ; C_{2}=0,3$.

Software $D 1(A)$ calculates the matrix of doses of the two-jet apparatus.

Selection of weight coefficients, is conducted by mixing the two laws of normal distribution.

Along the lines of equal irrigation doses increase in the irrigation uniformity can be noted. Excess irrigation is observed on the horizontal and vertical lines connecting the centers of rotation 
centers of the apparatuses, and there is insufficient irrigation at the intersection of the diagonals. The uniformity estimation showed that the effective irrigation coefficient is 0.893 .

The use of additional nozzle to equalize the water distribution along the radii proved to be effective, the best simulation result was obtained.

The coefficient of effective watering is more than 0.7 with installation step of devices of less than $37 \mathrm{~m}$. Uniformity according to Christiansen is more than $80 \%$ in the same range of distances between the apparatuses.

Discussion and conclusion. The method of modeling the water distribution by sprinklers can be used in the design of new and modernization of existing machines.

The considered examples can be used to optimize the placement of apparatus on «Volzhanka» and «Dnepr» machines.

According to the results of the work, number of conclusions can be formulated:

1. Probabilistic mathematical models of the sprinkling process make it possible to optimize the positioning of the apparatuses according to the criteria of irrigation uniformity.

2. Programs for modeling water distribution by devices from four positions are applicable only when the distance between the positions is greater than the radius of the sprinkling zone. In this case irrigation uniformity indicators do not meet agrotechnical requirements.

3. Optimization of the positioning of the apparatus in twelve positions provides excellent indicators of irrigation uniformity.

4. Optimization programs and techniques used in the research are applicable to optimize the distribution of other liquids in agricultural technologies, for example, for the distribution of pesticides.

\section{References}

1. Chernovolov, V.A. Methodology for simulating the sprinkling process by long-range devices working in a circle / V.A. Chernovolov, L.V. Kravchenko // Bulletin of the AIC of Stavropol. - 2014. - № 3 (15). - pp. 68-72.

2. Chernovolov, V.A. Mathematical modeling of the processes of distribution of liquids in agricultural technologies: monograph / V.A. Chernovolov, L.V. Kravchenko. - Zernograd: AzovBlack Sea Engineering Institute of FSBEI HE Dons State Agrarian University, 2016. - 208 p.

3. Kravchenko, L.V. Calculation of sprinkling efficiency indicators on the area between four single-nozzle apparatuses / V.A. Chernovolov, L.V. Kravchenko // Certificate of State Registration of Computer Program No. 2014662137 dated 11/24/2014.

4. Kravchenko, L.V. Calculation of sprinkling efficiency indicators with single-jet devices working at twelve positions / V.A. Chernovolov, L.V. Kravchenko, O.V. Butkova // Certificate of state registration of computer programs № 2015616299 of 06/06/2015.

5. Kravchenko, L.V. The uniformity of irrigation with single - jet and multi - jet sprinkler apparatus of rie action / V.A. Chernovolov, L.V. Kravchenko // Applied and fundamental studies proceedings of the 7th international academic conference. Publishing house «Science and innovation center». - 2014. - P. 199-211. 
Authors:

Chernovolov Vasiliy Alexandrovich, Azov-Black Sea Engineering Institute of FSBEI HE Don State Agrarian University (21 Lenin st., Zernograd, Russian Federation), Doctor of Technical Sciences, professor

Kravchenko Ljudmila Vladimirivna, Don State Technical University (1st Gagarin Square, Rostovon-Don, Russian Federation), Doctor of Technical Sciences, Associate professor

Litvinov Vladimir Nikolaevich, Azov-Black Sea Engineering Institute of FSBEI HE Don State Agrarian University (21 Lenin st., Zernograd, Russian Federation), Candidate of Technical Sciences, Head of the Thermal Engineering and Information Management Systems department

Nikitina Alla Valeryevna, Southern Federal University (Chekhov str., 2, Taganrog, Russian Federation), Doctor of Technical Science, Associate professor.

Filina Alena Aleksandrovna, Supercomputers and Neurocomputers Research Center, Co Ltd. (Italyansky lane, 106, Taganrog, Russian Federation), Candidate of Technical Science, Researcher 


\section{Вероятностное моделирование процессов дождевания*}

\section{В. А. Черноволов ${ }^{* *}$, Л. В. Кравченко ${ }^{* * *}$, В. Н. Литвинов ${ }^{* *}$, А. Н. Никитина ${ }^{* * * *}$,}

\section{А. А. Филина ${ }^{* * * * *}$}

Азово-Черноморский инженерный институт, г. Зерноград, Российская Федерация

Донской государственный технический университет, г. Ростов-на-Дону, Российская Федерация

Южный федеральный университет, г. Ростов-на-Дону, Российская Федерация

ООО «НИЦ супер-ЭВМ и нейрокомпьютеров».

Статья посвящена разработке модели процесса дождевания, находящейся в отношении вероятностного подобия к моделируемому процессу, численная реализация которой позволяет выполнить расчет матрицы доз полива в зоне дождевания, или на зачётной площадке. Исследование выполнено с применением системного анализа и вероятностного моделирования. Равномерность распределения жидкости по площади до 2004 года на основании РД 10.11.1-9-89 оценивали коэффициентом эффективного полива, коэффициентом недостаточного полива, коэффициентом избыточного полива. После введения межгосударственного стандарта ИСО 7749-2-2004 - коэффициентом Христиансена. Разработаны новые математические модели и программное обеспечение для вероятностного моделирования процесса дождевания. При построении модели использовались теорема о совмещении событий и теорема А.М. Ляпунова. Для примера был проведен анализ работы двенадцати дождевальных аппаратов. Представленный вычислительный эксперимент выполнен для оптимизации позиционирования аппаратов по критериям равномерности орошения и по коэффициенту полноты учета воды, попадающей на зачетную площадку. Обсуждение и заключения. Полученные результаты могут быть использованы в процессе оптимизации размещения аппаратов на машинах «Волжанка» и «Днепр». Вероятностные математические модели процесса дождевания позволяют оптимизировать позиционирование аппаратов по критериям равномерности орошения. Программы моделирования распределения воды аппаратами с четырех позиций применимы только при расстоянии между позициями большем радиуса зоны дождевания. Показатели равномерности орошения при этом не соответствуют агротехническим требованиям. Оптимизация позиционирования аппаратов по

\footnotetext{
* Работа выполнена при частичной поддержке гранта РФФИ № 19-07-00623.

** E-mail: gulshat.islamova.2017@mail.ru.

*** E-mail: chernovolov.v@mail.ru, LitvinovVN@ rambler.ru.

****E-mail: lusya306@yandex.ru.

**** E-mail: nikitina.vm@ gmail.com.

***** E-mail: j.a.s.s.y@mail.ru.
} 
двенадцати позициям дает отличные показатели по равномерности орошения. Программы и методики оптимизации, использованные при исследовании, применимы для оптимизации процессов распределения других жидкостей в агротехнологиях, например для распределения пестицидов.

Ключевые слова: расчет показателей равномерности, равномерность дождевания, равномерность полива, коэффициент равномерности Христиансена, коэффициент эффективного полива, коэффициент недостаточного полива, коэффициент избыточного полива.

\section{Авторы:}

Черноволов Василий Александрович, Азово-Черноморский инженерный институт ФГБОУ ВО Донской ГАУ (РФ, г. Зерноград, ул. Ленина, 21), Доктор технических наук, профессор.

Кравченко Людмила Владимировна, Донской государственный технический университет (344000 Ростов-на-Дону, пл. Гагарина, д. 1), Доктор технических наук, доцент.

Литвинов Владимир Николаевич, Азово-Черноморский инженерный институт ФГБОУ ВО Донской ГАУ (РФ, г. Зерноград, ул. Ленина, 21), Кандидат технических наук, доцент.

Никитина Алла Валерьевна, Южный Федеральный Университет (347928, Россия, Ростовская область, г. Таганрог, пер. Некрасовский, 44), Доктор технических наук, профессор.

Филина Алёна Александровна, Научно-исследовательский центр супер-ЭВМ и нейрокомпьютеров (347900, Россия, Ростовская область, г. Таганрог, пер. Итальянский, дом 106), Кандидат технических наук, научный сотрудник. 